\title{
Спортивный арбитражный суд в Лозанне: международно-правовые вопросы организации и деятельности
}

Беляев С.A.*

\section{Возникновение арбитражных органов в области спорта}

В последнее время международная юридическая общественность все больше внимания уделяет актуальным вопросам организации и деятельности международных судебных, квазисудебных и арбитражных учреждений, среди которых одним из наиболее «молодых» и динамично развивающихся является Спортивный Арбитражный Суд в Лозанне (CAC) ${ }^{1}$.

История этого арбитражного учреждения, являющегося независимым учреждением по разрешению споров, возникающих в области спорта, начинается в 1983 г., когда Международный Олимпийский Комитет утвердил учредительные документы САС, которые вступили в силу 30 июня 1984 года.

Уже в первые годы своего существования Суд вынес решения по делам, касавшимся обшественно значимых споров по вопросам гражданства атлетов, трудовых соглашений, уступок прав телевизионной трансляции спортивных программ, контрактов по спонсорингу, лицензионных соглашений и других вопросов, тесно связанных с такой важной сферой жизни современного общества, как спорт. ${ }^{2}$

В 1993 году решение Спортивного Суда в деле Э. Гюндель против Международной конно-спортивной федерации ${ }^{3}$ было впервые обжаловано в публично-правовом иске в Федеральном суде Швейцарии на основании предполагаемой зависимости и пристрастности Суда.

\footnotetext{
- Беляев Сергей Алексеевич - кандидат юридических наук (Дипломатическая академия, Москва); магистр права и дипломатии (Флетчеровская школа права и дипломатии, Бостон); консультант по международному и европейскому праву, Адвокатская фирма Энгельманн Горев-Дрозд (Франкфурт-на-Майне); член Спортивного Арбитражного Суда (Лозанна).

${ }^{1}$ Французский термин - Tribunal arbitral du Sport (TAS), английская версия - Court of Arbitration for Sport (CAS). Возможны переводы: Спортивный третейский суд или Арбитражный суд в области спорта.

${ }^{2}$ Cм.: M. Reeb, Le tribunal arbitral du Sport. CM.: http://www.tas-cas.org.

${ }^{3}$ TAS $92 / 63$ G. c. FEI, Receuil des Sentences du TAS 1986-1998.
} 


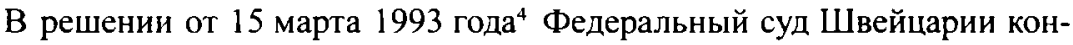
статировал, что САС не зависит от стороны спора - Международной конно-спортивной федерации - и является подлинно независимым и объективным арбитражным учреждением, решения которого обладают той же исполнительной силой, что и решения судов общей юрисдикции.

Вместе с тем Федеральный суд обратил внимание в своем решении на многочисленные связи, которые существовали между Спортивным Арбитражным Судом в Лозанне и Международным Олимпийским Комитетом, который, например, в этот период прямо и полностью финансировал работу Суда. Понятно, что в случае потенциального оспаривания решения МОК Спортивный Арбитражный Суд не мог бы рассматриваться в качестве независимого от Комитета учреждения. В результате было принято решение о проведении реформы организации и деятельности Спортивного Суда.

22 июня 1994 года представители Международного Олимпийского Комитета, 31 Международной спортивной федерации и Ассоциации национальных олимпийских комитетов подписали в Париже Конвенцию по вопросам создания нового органа - Международного совета по арбитражу в спорте, в ведение которого был переведен Спортивный Арбитражный Суд, и признали подсудность своих споров этому Суду, взяв на себя обязательство включить в свои уставные документы арбитражные оговорки, предусматривающие обращение в САС для разрешения споров, возникающих в области спорта.

Помимо этого, в ходе реформы 1994 г. в составе Суда были созданы две независимых друг от друга Палаты (первая - общего типа для разбирательств в основной инстанции, вторая - апелляционная), а также принят Арбитражный Кодекс в области спорта.

Вступление в силу Конвенции, получившей название Парижской, а также расширение практики использования арбитражных соглашений в уставах спортивных организаций и оговорок в контрактах, касающихся спорта, вызвали активизацию уже тогда интенсивной деятельности САС. В последующие годы были осушествлены дополнительные реформы, которые привели к созданию с 1996 г. так называемых «децентрализованных бюро» Суда на других континентах, выполняющих некоторые функции Секретариата Суда, а также к созданию в 1996 г. Палаты Суда ad hoc для зимних Олимпийских игр, в 1998 г.

\footnotetext{
${ }^{4}$ Recueil Officiel des Arrêts du Tribunal fédéral 119 II 271.
} 
Палат ad hoc для летних Олимпийских игр и Игр Британского содружества наций, а в 2000 г. - Палаты ad hoc для проведения чемпионата Европы по футболу. В 2003 году был утвержден Регламент Палаты ad hoc в преддверии Олимпийских игр 2004 r., ставшей тем самым институционализированным органом.

Таким образом, основными правовыми источниками функционирования САС на современном этапе являются Олимпийская хартия, Парижская конвенция, Арбитражный Кодекс в области спорта, включающий Устав органов по решению споров в области спорта, Регламент, Регламент по посредничеству, Регламент по арбитражу на Олимпийских играх, а таюже приложения (образцы арбитражных соглашений, оговорок и соглашения о посредническом производстве, шкала оплаты услуг). ${ }^{5}$

К общим источникам деятельности САС относятся также Антидопинговый Кодекс Международного олимпийского движения ${ }^{6}$, Швейцарский Закон о международном частном праве от 18 декабря 1987 года и Нью-Йоркская Конвенция о признании и приведении к исполнению арбитражных решений от 10 июня 1958 года. Помимо этого, при рассмотрении и решении конкретных дел используются прецедентная практика самого суда и некоторые дополнительные источники, которые будут упомянуты ниже.

\section{Основы организации Международного совета} по арбитражу в спорте и Спортивного Арбитражного Суда

Устав органов по решению споров в области спорта7 начинается с общих положений, относящихся к организации как Международного совета по арбитражу в спорте, так и Спортивного Арбитражного Суда и определяющих общие цели и принципы их создания и функционирования.

Статья S4 определяет порядок формирования состава Международного совета по арбитражу в спорте (MCAC). В Совет входит 20 членов, являюшихся юристами высокого уровня и назначаемых следующим образом:

\footnotetext{
' Смотрите: Code of Sport-related Arbitration and Mediation Rules, Edition 2004; Digest of CAS Awards (I and II); CAS Awards - Sydney 2000 (См.: http://www.tas-cas.org).

${ }^{\circ}$ См. текст: http://www.olympic.org.

'Здесь и далее цитируется по тексту в: Code of Sport-related Arbitration and Mediation Rules, Edition 2004.
} 
а) четыре члена назначаются Международными федерациями, среди которых три - Олимпийскими Международными федерациями летних Олимпийских игр и один - Олимпийскими Международными федерациями зимних Олимпийских игр, которые избирают их из своего состава или вне его;

b) четыре члена назначаются Ассоциацией национальных Олимпийских комитетов, избирающей их из своего состава или вне него;

c) четыре члена назначаются Международным Олимпийским Комитетом, избирающим их из своего состава или вне его;

d) четыре члена назначаются двенадцатью членами МСАС, которые были назначены в предыдущих трех категориях после соответствующих консультаций, с тем чтобы соблюсти интересы атлетов;

е) четыре члена избираются шестнадцатью членами МСАC, назначенными в предыдущих четырех категориях, среди лиц, независимых от организаций, назначающих других членов МСAC (ст. S4).

Статья 5 определяет, что члены Совета назначаются на возобновляемые 4 года и что при вступлении в должность они подписывают декларацию об исполнении своих функций в личном качестве, полностью объективно и независимо, в соответствии с положениями Кодекса. Они обязаны соблюдать конфиденциальность. Члены Совета не могут совмещать свой мандат с полномочиями арбитров или действовать в качестве консультантов какой-либо из сторон при разбирательстве дел в Спортивном Арбитражном Суде.

Если один из членов Совета подает в отставку или не может выполнять обязанности в силу других причин, он замещается согласно процедуре, применявшейся при его назначении.

Статья S6 перечисляет функции Совета, среди которых утверждение и изменение Арбитражного Кодекса, а также избрание на срок 4 года своего Президента (по предложению Международного Олимпийского Комитета), двух вице-президентов (один - по предложению Международных федераций, один - по предложению национальных Олимпийских комитетов), двух Президентов Палат Суда и их заместителей. Помимо этого, Совет назначает и отводит арбитров, финансирует Суд, назначает и принимает по предложению Президента отставку Генерального секретаря Суда, создает арбитражные региональные и местные органы постоянного или временного характера, а также выполняет некоторые другие функции, имеющие целью обеспечение прав сторон и независимости арбитров (ст. S6.10). Статья S9 опреде- 
ляет, что Президент Совета является одновременно Президентом Суда.

Раздел С Арбитражного Кодекса посвяшен определению правового статуса Спортивного Арбитражного Суда. Статья S12 гласит, что Суд создает составы, которые с помошью арбитражного разбирательства или посредничества разрешают споры в области спорта, наблюдает за соблюдением процессуальных правил Регламента и предоставляет составам соответствующую инфраструктуру для работы.

Функциями составов являются разрешение споров в рамках разбирательства в первой и единой инстанции (производство общего типа) или в рамках апелляционного производства, а также подготовка консультативных заключений по запросам уполномоченных организаций.

Арбитры включаются Советом в список на возобновляемый срок четыре года. Список пересматривается один раз в четыре года, и арбитры исполняют свои полномочия с 1 января года, следующего за утверждением списка.

Статья S14 определяет порядок выдвижения кандидатов на должность членов Суда:

- 1/5 арбитров избирается среди лиц, предложенных Международным Олимпийским Комитетом и выбираемых им из своего состава или вне его;

- 1/5 арбитров избирается среди лиц, предложенных Международными федерациями и выбираемых ими из своего состава или вне его;

- 1/5 арбитров избирается среди лиц, предложенных национальными Олимпийскими комитетами и выбираемых ими из своего состава или вне его;

- 1/5 арбитров избирается после соответствующих консультаций в целях соблюдения интересов атлетов;

- 1/5 арбитров выбирается среди лиц, независимых от вышеуказанных организаций, имеющих право предлагать арбитров (ст. S14).

Список публикуется, в частности, и в Интернете ${ }^{8}$. В отношении прозрачности списка арбитров Федеральный суд Швейцарии по подеркнул в недавнем решении желательность того, чтобы в списке арбитров указывалась организация, которая предложила его кандидатуру для избрания, с тем чтобы истцы могли определить независимость арбитра от организации, которая может стать стороной спора.

${ }^{8}$ CM.: http://www.tas-cas.org.

${ }^{4}$ A. et B. c. Comité International Olympique, Fédération Internationale de Ski, Tribunal Arbitral du Sport, Arrêt du 27 mai 2003. P. 3.3.3.2. C.м.: http://www.tas-cas.org. 
Согласно статье S16, Совет следит за тем, чтобы «лица, включенные в состав списка, отражали, по мере возможностей, справедливое представительство континентов и различных правовых культур». Если один из членов Суда по каким-либо причинам выбывает из списка, то до конца оставшегося срока его замещают другим арбитром в порядке, который был предусмотрен для его назначения (ст. S17).

При вступлении в должность арбитры подписывают декларацию об исполнении своих обязанностей в личном качестве, полностью независимо и объективно, в соответствии с положениями Арбитражного Кодекса (ст. S18). Согласно статье S19, арбитры обязаны соблюдать конфиденциальность и не разглашать в отношении третьих лиц информацию, имеющую отношение к разбирательству в Суде.

\section{Общее и апелляционное производство в САС}

Как уже отмечалось, в САС существуют два основных типа арбитражного производства. В первом случае, когда речь идет о нарушении контрактных отношений, применяется производство в первой и единой инстанции. Для рассмотрения споров, возникающих в результате дисциплинарных решений федераций, ассоциаций или других спортивных организаций, существует апелляционное производство. В соответствии с этим в составе Суда существуют две Палаты - Палата общего арбитража и Апелляционная арбитражная Палата (ст. S20). Apбитры не входят исключительно в ту или иную Палату и могут быть назначены в составы ("la formation" - французская версия, "the panel" - английская версия) и того, и другого типов разбирательств.

Статья S27 гласит, что на рассмотрение Суда могут передаваться все споры, прямо или косвенно связанные со спортом, - коммерческого характера (к примеру, споры, возникающие из контрактов по спонсорингу, продаже прав телевизионной трансляции, организации спортивных мероприятий, трансферту игроков, по отношениям между атлетами и тренерами или клубами, из агентских соглашений, исков гражданской ответственности) или дисциплинарного характера, возникающие в результате решения дисциплинарного, контрольного или арбитражного органа спортивной ассоциации, федерации или организации (например, дела по допинговому контролю, квалификации спортсменов, гомологизации спортивных мероприятий, грубому поведению на спортивном мероприятии, оскорблению арбитра игры, жестокому отношению к спортивным лошадям). ${ }^{10}$ 
Та же статья определяет достаточно широкий круг споров, подпадающих под юрисдикцию Суда:

«Эти споры могут затрагивать принципиальные вопросы, относящиеся к спорту или материальным интересам, или иные вопросы, возникающие в связи с практикой или развитием спорта и в целом с любой деятельностью, имеющей отношение к спорту».

Правосубъектный состав Суда включает любое физическое или юридическое лицо, обладающее гражданско-правовой дееспособностью - атлет, клуб, спортивная федерация, организатор спортивного мероприятия, спонсор и т.д.

Вместе с тем, существуют условия приемлемости (подсудности, допустимости) споров для арбитражного разбирательства в САС: стороны должны иметь письменное соглашение об обращении в Суд для рассмотрения возникшего спора. Это может быть отдельное разовое соглашение ("arbitration agreement", “compromis arbitral"), либо положение (оговорка), входящее в контракт ("arbitration clause", "clause arbitrale") $)^{11}$ или в уставной акт или регламент юридического лица. ${ }^{12}$ Таким образом, стороны могут договориться об обращении в Суд как до возникновения спора, так и после его возникновения.

Авторы Регламента и соглашений (оговорок) обращают внимание на то, что действительность арбитражного положения об исключительной компетенции САС признается не во всех национальных системах права, и рекомендуют федерациям и организаторам мероприятий предварительно проверить законность такой нормы в своем собственном национальном правопорядке. ${ }^{13}$

Общим условием приемлемости предмета спора является среди прочих требование к тому, чтобы он носил правовой характер, а не касался исключительно правил игр или соревнований. ${ }^{14}$ Представляется, что судебная практика должна провести четкую квалификацию этих понятий ввиду того, что и вторая упомянутая категория предметов оспаривания - правил игр и соревнований - носит в конечном счете правовой характер.

Особенностью приемлемости дел при апелляционном производстве является необходимость для истца исчерпать «предварительные пра-

\footnotetext{
${ }^{10}$ Cм.: Guide de l'Atbitrage, Tribunal Arbitral du Sport, Lausanne, 2004. P. 10.

"См. прилагаемые к статье образцы соглашений и оговорок.

${ }^{12} \mathrm{CM}$. прилагаемые к статье образцы оговорок и соответствующие декларации атлетов.

${ }^{13}$ Code of Sport-related Arbitration and Mediation Rules, Edition 2004. P. 155.
} 
вовые средства, которыми он обладает в силу учредительных документов или уставов данной спортивной организации» (ст. R47). При отсутствии в уставных документах спортивной федерации указания на сроки обжалования Регламент определяет для внесения заявления срок 21 день со времени получения оспариваемого решения или, в соответствии с международной практикой других судебных и арбитражных учреждений, срок 21 день со времени получения решения последней инстанции, обращение к которой было необходимо для исчерпания средств внутренней защиты.

Общие условия отправления производства, включая методы исчисления процессуальных сроков, для двух типов разбирательств (общего и апелляционного) определяются в ст. R31-32 Регламента.

Сторона, желающая обратиться в Суд, должна направить в Секретариат САС при производстве общего типа исковое арбитражное заявление, а при апелляционной процедуре - апелляционное заявление. Требования к формальному содержанию этих документов изложены в Регламенте (соответственно ст. R38 и R48).

Наиболее распространенной практикой является положение, когда арбитражное разбирательство осуществляется в составе трех арбитров. В таком случае каждая сторона выбирает арбитра, включенного в список САС, после чего два назначенных арбитра или, в случае несогласия, Президент соответствующей Палаты Суда избирают третьего, который выполняет функции Президента состава (ст. R40.2). Если стороны согласны или если Суд считает это уместным, может быть с учетом природы и значения дела назначен единоличный арбитр.

Профессиональные требования к арбитрам определяются ст. R33: помимо принципа независимости, Регламент указывает на то, что арбитр должен фигурировать в списке, утвержденном Международным советом по арбитражу в спорте, владеть языком арбитражного разбирательства и обладать необходимым временем для проведения разбирательства в кратчайшие сроки.

Положение о выборе арбитра исключительно из утвержденного списка вызвало дискуссию в юридической литературе о САС: некоторые авторы отдали предпочтение свободному выбору арбитров без утвержденного списка, обосновывая это потребностью в большей свободе

14 A. et B. c. Comité International Olympique, Fédération Internationale de Ski, Tribunal Arbitral du Sport, Arrêt du 27 mai 2003. P. 2.1, cm.: http://www.tas-cas.org.; Francois Vailloz, Règles de droit et règles de jeu en droit du sport - l'example du dopage, in: PJA, 1999. P. 161,165 . 
воли сторон при выборе арбитров. ${ }^{15}$ Оппоненты такого подхода выдвинули доводы о необходимости специализации и большей независимости арбитров от сторон, с тем чтобы они не выступали в качестве адвокатов сторон. Федеральный суд Швейцарии встал на сторону второй точки зрения в деле А. и В. против Международного Олимпийского Комитета, Международной федерации лыжного спорта и Спортивного Арбитражного Суда. ${ }^{16}$

Хотя интерпретация принципа независимости третейских судей весьма многогранна, обшепринятым требованием является отсутствие каких-либо особых, прежде всего финансовых, отношений с той или другой стороной. ${ }^{17}$ Как и в других арбитражных учреждениях, если существуют обстоятельства, которые могут поставить под вопрос независимый статус арбитра, он обязан незамедлительно сообшить об этом руководству Суда (cт. R33). Статьи R34, R35 и R36 регулируют вопросы заявления самоотводов, отводов и замещения арбитров.

После внесения искового или апелляционного заявления появляется возможность истребования мер по обеспечению ("provisional or conservatory measures", "mesures provisionnelles et conservatoires"). Определение по их принятию выносится Президентом соответствующей Палаты, если дело еще не передано на разбирательство в состав арбитража, а если передано, то составом арбитражного разбирательства. Заявление стороны о принятии таких мер означает, что она отказывается от требования о принятии таких мер на национальном уровне. Однако это положение не относится к арбитражному производству общего типа (ст. R37). Президент Палаты выносит определение по поводу обеспечительных мер после ознакомления с мнением противоположной стороны.

При производстве в Палате общего арбитража после получения копии заявления сторона-ответчик готовит свой ответный меморандум (отзыв). После возможного дополнительного, повторного обмена меморандумами стороны приглашаются на заседание для изложения своих позиций, представления доказательств и выступлений.

15 Например, см.: Stephan Netzle, Das Internationale Sport-Schiedsgericht in Lausanne. Zusammensetzung, Zuständigkeit und Verfahrung, in: Sportsgerichtsbarkeit in Recht und Sport, Vol. 22. P. 9, ss. 12.

${ }^{16} \mathrm{~A}$. et B. c. Comité International Olympique; Fédération Internationale de Ski, Tribunal Arbitral du Sport, Arêt du 27 mai 2003. CM.: http://www.tas-cas.org.

"Le Statut de l'Arbitre, Supplément spécial, Bulletin de la Cour Internationale d'Arbitrage de la CCI, 1995. 
Согласно ст. \$30 Регламента, стороны спора в ходе разбирательства дел на слушаниях САС могут по своему выбору иметь представителей или консультантов, как имеющих статус адвокатов, так и не имеющих.

Общепринятым процессуальным принципом арбитражного производства является равенство сторон. Бывший Президент Международного Суда ООН М. Беджауи в обшем виде определяет основополагающую процессуальную трилогию международного арбитража так: обеспечение равенства сторон, соблюдение прав защиты, справедливое производство во всех отношениях. ${ }^{18}$ Вместе с тем, как известно, принцип равенства сторон не может быть абсолютным; в литературе можно встретить точку зрения, что «процессуальные возможности могут быть, очевидно, подчинены разумным условиям, которые не должны являться дискриминационными». ${ }^{19}$

В делах, подпадающих под юрисдикцию Палаты общего арбитража, стороны вольны избрать право, применимое для разрешения существа спора (ст. R45). Более того, стороны могут согласиться, чтобы состав принимал решение ex aequo e bono. При отсутствии согласия применяется швейцарское право (ст. R45). При апелляционной процедуре в CAC арбитры принимают решение на основе уставных документов федерации, действия которой обжалуются, и субсидиарно - на основе положений права, избранного сторонами, или на основе права государства, где зарегистрирована федерация. Возможно применение права по выбору состава, но в таком случае решение о выборе права должно быть мотивировано (ст. R57).

Состав имеет право истребовать дополнительные документы, вынести определения о необходимости вызвать и заслушать свидетелей или экспертов. Хотя права сторон в ходе состязательного производства в САС не идут так далеко, как в англосаксонской системе общего права, стороны спора имеют право через Суд истребовать документы, которые находятся в распоряжении или под контролем противоположной стороны (ст. R44.3).

Производство в Палате общего арбитража является конфиденциальным. Стороны спора, арбитры и персонал Суда обязаны не разглашать информацию, имеющую какое-либо отношение к спору. Арбитражные

\footnotetext{
${ }^{1 *}$ Mohammed Bedjaoui, L'Arbitre, ce personnage singulier, in: Le Statut de l'Arbitre, Supplément spécial, Bulletin de la Cour Internationale d'Arbitrage de la CCI, 1995. P. 138. ${ }^{19}$ Bernard Corboz, Le recours au Tribunal fédéral en matière d'arbitrage international, in: Sport-Joumal , 2002 II. P. 22.
} 
решения по общему правилу не публикуются. ${ }^{20}$ Апелляционная процедура не предусматривает особых правил конфиденциальности, хотя арбитры и персонал Суда обязаны соблюдать конфиденциальность в ходе производства.

Арбитражное решение принимается простым большинством голосов, а при равенстве голосов - Президентом состава (cr. R46). Оно вступает в законную силу для сторон со времени его передачи в Секретариат Суда (ст. R46). Этим производство САC в Лозанне отличается, например, от процедуры вынесения решений в Международном арбитражном суде Международной торговой палаты в Париже, где окончательное решение утверждается членами Суда, не являющимися арбитрами.

Когда речь идет о юридической природе решения САС, следует отметить, что решение является окончательным и подлежащим исполнению с момента нотификации о нем. Оно может быть, в частности, исполнено в случае отказа стороны от добровольного исполнения решения в силу Нью-йоркской Конвенции о признании и приведении к исполнению иностранных арбитражных решений (1958 г.), которая в настоящее время подписана более 125 государствами.

Обращает на себя внимание, что при апелляционном производстве Суд обладает правом рассматривать как факты, так и их юридическую квалификацию ("the facts and the law", "les faits et les droits") и, как следствие, полномочиями не только по отмене и направлению дела на пересмотр в последнюю инстанцию, но и по изменению дисциплинарных наказаний (ст. R57), постановляя, в частности, какой «должна» быть санкция. ${ }^{21}$ Такой объем полномочий идет, несомненно, дальше практики обычных международных арбитражных разбирательств. В этом смысле небезынтересной представляется возможная дискуссия о применении некоторых положений Федерального закона о международном коммерческом арбитраже (ст. 233, п. 4 АПК РФ).

На основе сложившейся практики процедура в Палате общего арбитража продолжается от 6 до 12 месяцев. При апелляционном производстве решение обычно выносится в течение 4 месяцев, считая со времени внесения апелляционного заявления.

${ }^{20}$ Однако с согласия сторон некоторые из них публикуются. См.: http://www.tas-cas.org.

${ }^{21}$ TAS 2004/A/549 G. Deferr \& RFEG c/FIG. P. 42. Tекст смотрите: http://www.tas-cas.org. 
Оспаривание решения САС в принципе возможно."2 Однако основания для обжалования арбитражных решений Спортивного Суда в Федеральном суде Швейцарии крайне ограничены. К их числу относятся: отсутствие компетенции Суда, неправомочный состав арбитража, нарушение основополагающих процессуальных правил (например, право быть лично заслушанным), рассмотрение вопросов, выходяших за пределы предмета заявления, отказ от рассмотрения заявленных жалоб или несоответствие решения публичному порядку ("public order", "ordre public"), который, как известно, может иметь процессуальный или материальный характер.

Регламент определяет финансовые аспекты арбитражных разбирательств в Лозанне. При производстве в Палате общего арбитража, помимо регистрационного сбора (500 швейц. франков), стороны оплачивают накладные расходы и гонорары арбитров, которые подсчитываются на основе фиксированной шкалы, прилагаемой к Арбитражному Кодексу в области спорта. ${ }^{23}$ Апелляционная процедура является бесплатной при условии оплаты начальных услуг (регистрационного сбора) Секретариата Суда (500 швейц. франков).

Местом пребывания САС является Лозанна (ст. S28), но с 1996 г. существуют два «децентрализованных» бюро - в Сиднее и НьюЙорке, - подчиненных Секретариату САС в Лозанне. Функции «децентрализованных» бюро касаются исключительно вопросов процессуального характера и направлены на упрошение доступа к САС в Океании, включая Австралию, и в Северной Америке.

Разбирательство осуществляется на французском и английском языках. В некоторых случаях Суд с согласия сторон может использовать другие языки. Использование переводчика оплачивается частично или полностью Судом (ст. S29).

\section{Арбитражное разбирательство на Олимпийских играх}

Регламент арбитражного производства на Олимпийских играх был утвержден Международным советом по арбитражу в спорте 14 октября 2003 года на основе ст. 74 Олимпийской хартии и ст. S6 (параграфы 1, 8 и 9), S8, S23 и R69 Арбитражного Кодекса в области спорта.

${ }^{22} \mathrm{C}_{\mathrm{M}}$ : Bernard Corboz, Le recours au Tribunal fédéral en matière d'arbitrage international, in: Sport-Journal, 2002, 11.

${ }^{23}$ Code of Sport-related Arbitration and Mediation Rules, Edition 2004. P. 158-161. 
Регламент арб́итражного разбирательства на Олимпийских играх стал составной частью этого Кодекса. ${ }^{2+}$

Целью Регламента является регулирование арбитражного разбирательства дел, возникших в силу ст. 74 Олимпийской хартии в период проведения Олимпийских игр и десяти дней, предшествующих их открыгию. Заявления об арбитраже в силу этого Регламента должны касаться решений Международного Олимпийского Комитета, национальных Олимпийских комитетов, Международных федераций и Организационного комитета Олимпийских игр. В силу ст. 1 предварительно должны быть исчерпаны средства внутренней защиты в самой организации, исключая положение, когда эти процедуры могут сделать рассмотрение заявления недействительным.

Арбитражное разбирательство в рамках Олимпийских игр осуществляется Палатой ad hoc, состоящей из арбитров, фигурируюших в особом списке, а также Президента и Секретариата Палаты. Вместе с тем в Регламенте арбитража на Олимпийских играх отсутствует положение о том, что в специальном списке должно быть обеспечено справедливое представительство континентов и правовых культур.

Данный список арбитров утверждается Бюро Международного совета по арбитражу в спорте исключительно из общего списка состава членов Спортивного Арбитражного Суда. Таким же образом избирается Президент Палаты. Секретариат Палаты создается Секретариатом САС и находится в подчинении Генерального секретаря Суда. Местом нахождения Палаты и составов является Лозанна, но они могут осуществлять свою работу на месте проведения Олимпийских игр или там, где сочтут целесообразным.

Применимым (процессуальным) правом арбитражного разбирательства на Олимпийских играх является глава 12 швейцарского Закона о международном частном праве (ст. 7 Регламента). Статьи 8 и 9 Регламента определяют условия внесения и требования к оформлению заявлений, вносимых в силу упомянутой ст. 1 Регламента.

В отличие от общей, наиболее распространенной процедуры назначения арбитров сторонами спора, на Олимпийских играх арбитры состава и Президент состава назначаются Президентом Палаты на основе особого списка, упомянутого в ст. 3. В отдельных случаях возможно назначение единоличного арбитра.

\footnotetext{
${ }^{24}$ Здесь и далее цитируется по тексту в: Code of Sport-related Arbitration and Mediation Rules, Edition 2004. P. 125-145.
} 
Арбитры, включенные в список, должны быть независимыми от сторон спора, находиться в распоряжении Палаты в течение всего периода Олимпийских игр в месте их проведения (ст. 12 Регламента).

Статья 13 определяет причины и условия осушествления самоотвода и отвода арбитров, где главным обстоятельством являются «обоснованные сомнения» в независимости арбитра. Решение принимается Президентом Палаты незамедлительно после ознакомления с мнением сторон и арбитра.

В силу ст. 14, при некоторых условиях, Президент Палаты или состав арбитров могут принять определение об обеспечительных мерах ("stay of decision challanged and preliminary relief of extreme urgency", "effet suspensif ou mesures provisionnelles d"extrкme urgence"), которые могут приостановить действие оспариваемого решения. Среди прочих условий для принятия таких мер указывается возможность «невосполнимого ущерба» ("irreparable harm", "dommage irrŭparable"), который может быть причинен заявителю в случае исполнения оспариваемого решения (cr. 14).

Применимым материальным правом в силу ст. 18 Регламента являются Хартия Олимпийских игр, соответствуюшие учредительные документы данной федерации, ассоциации, организации или клуба, а также общие принципы права и нормы права, которые состав считает целесообразными. Решение должно быть вынесено в течение 24 часов, считая от времени внесения заявления. Этот срок может быть продлен по решению Президента Палаты.

Согласно ст. 19, арбитражное решение вступает в силу с момента опубликования его резолютивной (диспозиционной) части и не может быть обжаловано (ст. 21). Мотивация может быть опубликована позже.

При определенных условиях состав может вынести решение в части, передав оставшуюся часть предмета спора на общее разбирательство Спортивного Арбитражного Суда (ст. 20а), при этом возможно принятие мер по обеспечению исполнения решения в этой части до их отмены в рамках обычной процедуры в САС.

Все услуги Палаты в ходе разбирательства в Палате для Олимпийских игр являются бесплатными. Однако собственные расходы сторон, включая адвокатские или экспертные гонорары, а также расходы на переводчиков и свидетелей, оплачиваются сторонами спора. 


\section{Посредническое производство \\ в Спортивном Арбитражном Суде}

Арбитражный Кодекс в области спорта предусматривает возможность еше одного механизма разрешения споров - посредничества, которое регулируется отдельным Регламентом посредничества. ${ }^{25}$ Посредничество в практике САС следует отличать от процедуры примирения, предусмотренной в ст. R42 в рамках производств общего типа, согласно которой Президент Палаты до передачи дела для разбирательства в состав предпринимает попытку примирения сторон, которая в случае успеха может стать с согласия сторон предметом арбитражного решения.

Процедура посредничества носит рекомендательный и неформальный характер (ст. 1 Регламента о посредничестве). Она основана на соглашении о посредничестве (см. прилагаемый образец соглашения о посредничестве $)^{26}$, где каждая сторона берет на себя обязательство добросовестно преодолеть разногласие с другой стороной непосредственно или с помощью посредника САС, с тем чтобы достигнуть решения спора, имеющего отношение к спорту (ст. 1). Та же статья гласит, что данное производство применимо исключительно для разбира'тельств в Палате общего типа.

Сторона спора, которая желает начать процедуру посредничества, направляет прошение (“the request", "la demande") в Секретариат Суда. Условием начала процедуры является наличие посреднического соглашения, которое может быть либо включено в форме оговорки в контракт, либо заключено в форме отдельного соглашения (ст. 2).

В целях отправления производства посредничества существует список посредников, которые избираются Международным советом по арбитражу в спорте (ст. S6.3 Устава органов по разрешению споров в области спорта).

Посредник назначается из списка посредников Суда сторонами или, при отсутствии согласия, Президентом Суда после консультаций со сторонами (ст. 5 и 6 Регламента). Производство посредничества осуществляется в соответствии с соглашением сторон (ст. 8). Посредник располагает определенной автономией при урегулировании спора. Его функции заключаются в том, чтобы:

$\because$ См. здесь и далее: Code of Sport-related Arbitration and Mediation Rules, Edition 2004. P. 105-123.

${ }^{26}$ Code of Sport-related Arbitration and Mediation Rules, Edition 2004. P. 154-157. 
- опрсделить вопросы, являюшиеся гіредметом разногласий;

- способствовать пюреговорам между сторонами;

- предлагать варианты решений (ст. 9).

Согласно ст. 3 данного Регламента, если соглашение о посредничестве предусматривает применение данного Регламента, то он рассматривается в качествс составной части соглашения. Вместе с тем стороны посреднического производства могут согласиться применять другие процессуальные нормы. При отсутствии согласия сам посредник определяет правила производства посредничества (ст. 8). Вместе с тем Іредложения посредника не имеют императивной силы по решению слора по существу.

В случае успеха посредничество заканчивается подписанием трансакции сторонами (ст. 12). В случае неудачи посредничества стороны могут обратиться к арбитражу САС, при этом посредник не может быть назначен арбитром.

Каждая сторона посреднической процедуры оплачивает свою часть регистрационного сбора Суда. Стороны оплачивают, кроме того, административные расходы САС, а также гонорары и издержки посредника, которые определяются по шкале САС, при этом оплата услуг Секретариата Суда, экспертов, переводчиков распределяется между сторонами в равной пропорции.

\section{Консультативные заключения}

Помимо вышеуказанных типов пронзводств, Регламент Спортивного Арбитражного Суда ${ }^{27}$ предусматривает процедуру консультативного характера, позволяющую некоторым спортивным организациям испрашивать консультативное заключение Суда по любому правовому вопросу, касающемуся практики или развития спорта или любой деятельности, связанной со спортом, но вне ведущихся разбирательств в рамках существующих споров.

Круг организаций, уполномоченных испрашивать консультативные заключения, включает Международный Олимпийский Комитет, Международные федерации, национальные Олимпийские комитеты, ассоциации спортсменов, признанные Международным Олимпийским Комитетом, Организационный комитет Олимпийских игр (cT. R60).

По получению запроса Президент САC решает, может ли он быть предметом рассмотрения. В случае положительного мнения он назна-

${ }^{27}$ Code of Sport-related Arbitration and Mediation Rules, Edition 2004. P. 80-81. 
чает арбитра или состав из трех арбитров и его Президента и формулирует вопросы, которые они должны решить.

Состав может истребовать дополнительную информацию для подготовки и принятия заключения. Оно может быть опубликовано только с разрешения испрашивающей заключение организации. Заключение не является арбитражным решением и не имеет императивной силы (ct. R62).

Регламент не регулирует вопрос оплаты услуг арбитров при подготовке заключения, но следует исходить из того, что она определяется Президентом САС.

\section{Некоторые выводы}

В целом есть основания констатировать, что в настояшее время Спортивный Арбитражный Суд является арбитражным учреждением, обладающим широким объемом полномочий по разрешению споров, которые имеют отношение к спорту, и располагающим развитым процессуальным порядком, который был за последние годы разработан, апробирован и усовершенствован в ходе активной деятельности Суда.

Спортивный Арбитражный Суд находится в административном и финансовом ведении Международного совета по арбитражу в спорте. При этом Суд является согласно общепринятым стандартам независимым арбитражным учреждением в первую очередь на том основании, что главным критерием независимости является независимость от сторон; Совет по арбитражу в спорте не может являться стороной в споре и в силу своего состава не отражает интересы какой-либо из потенциальных сторон в спорах. Анализ вопроса о независимости САС был проведен в решении Федерального суда Швейцарии в деле А. и В. против Международного Олимпийского Комитета, Международной федерации лыжного спорта и Спортивного Арбитражного Суда от 27 мая 2003 года. ${ }^{28}$ Федеральный суд дал полностью положительный ответ по вопросу о степени независимости Спортивного Суда. ${ }^{29}$

Список арбитров Суда включает в настоящее время граждан государств всех континентов. С 1 января 2005 года в состав Суда впервые вошли арбитры, являюшиеся гражданами Российской Федерации

${ }^{28}$ A. et B. c. Comité International Olympique, Fédération Internationale de Ski, Tribunal Arbitral du Sport, Arrêt du 27 mai 2003. CM.: http://www.tas-cas.org.

${ }^{29}$ Вместе с тем это мнение нередко оспаривается в доктрине. См.: Philippe Meier, Cedric Aguet, L'Arbitrabilté du recours contre la suspension prononcée par une fédération sportive internationale, in: Journal du Travail, 2002. P. 56, note 6; Dietmar Hantke, Brauchen wir eine Sport-Schiedsgerichtsbarkeit? In: Zeitschrift für Sport und Recht, 1998. P. 187. 
и ряда других ведуших спортивных держав мира. Таким образом, представляется, что принцип справедливого представительства континентов и различных правовых культур (ст. S16) в целом соблюден.

Спортивный Арбитражный Суд решает споры путем вынесения арбитражных решений, которые имеют такую же исполнительную силу, что и решения национальных судов общей юрисдикщии. Помимо этого, Суд правомочен принимать консультативные правовые заключения, связанные со спортом, и оказывать услуги по посредничеству (и примирению) в целях достижения добровольного мирного урегулирования споров. Вместе с тем посредническое производство и запросы консультативных заключений не получили пока широкого распространения.

Суд создает также Палаты ad hoc, не имеющие постоянного характера, но ставшие постоянной практикой САС, в частности при проведении Олимпийских игр, Игр Британского Содружества наций, а также чемпионатов по некоторым видам спорта (в частности, по футболу). В таких Палатах применяются особые правила ускоренной процедуры.

Суд в Лозанне выносил в последние годы арбитражные решения в среднем более чем по 50 делам в год. По информации Секретариата Суда, в 2004 г. было зарегистрировано 270 дел, т.е. на 160 больше, чем в предыдущем году. Все более частой практикой становится обрашение в САС заявителей из Российской Федерации ${ }^{30}$ и новых независимых государств.

Следует отметить, что ряд международных спортивных федераций профессионального характера, не входящих в Олимпийское движение (шахматы, теннис, хоккей, баскетбол), остаются вне юрисдикции САС. Вместе с тем Олимпийским движением ведется работа по распространению арбитражных полномочий Суда на спортивные организации такого типа.

Положительные аспекты деятельности Спортивного Арбитражного Суда (определенная оперативность вынесения решений, конфиденциальность, бесплатность некоторых типов производств) и растущее число обращений в Суд свидетельствуют о том, что он становится все более авторитетным и эффективным средством решения споров, призванным, по словам бывшего Президента Международного Олимпийского Комитета X. Самаранча, стать «подлинным Верховным судом мирового спорта». ${ }^{3 !}$

\footnotetext{
${ }^{30}$ См. одно из последних решений: CAS Arbitration N CAS OG 04/001, Russian Olympic Committee versus Fédération Equestre Internationale (http://www.tas-cas.org).
} 


\section{ОБРАЗЦЫ ОГОВОРОК ${ }^{32}$}

1. Арбитражное производство общего типа.

1.1. Арбитражная оговорка, являющаяся частью контракта.

«Любой спор, возникающий из настоящего контракта или в связи с ним, будет передаваться на разбирательство исключительно в Спортивный Арбитражный Суд в Лозанне (Швейцария) и подлежать окончательному урегулированию в соответствии с Арбитражным Кодексом в области спорта».

Возможные уточнения.

«В состав будет(ут) входить 1 (или 3) арбитр(а)».

«Языком арбитража будет...».

1.2. Арбитражное соглашение, заключаемое после возникновения спора.

Краткое описание спора.

«Спор будет передан на рассмотрение исключительно в Спортивный Арбитражный Суд в Лозанне, Швейцария, и подлежать окончательному урегулированию в соответствии с Арбитражным Кодексом в области спорта».

- Вариант 1:

«В состав, создаваемый Спортивным Арбитражным Судом, будет входить единоличный арбитр, назначаемый Президентом соответствуюшей Палаты САС».

Вариант 2:

«В состав, создаваемый Спортивным Арбитражным Судом, будет входить 3 арбитра. Каждая сторона назначает следующего арбитра:

- истец: г-н/г-жа (имя арбитра, находящегося в списке арбитров САС); - ответчик: г-н/г-жа (имя арбитра, находящегося в списке арбитров CAC).

Эти два арбитра назначают Президента состава в течение 15 дней со времени подписания настоящего соглашения. В случае несогласия в течение этого срока Президент соответствуюшей Палаты назначает Президента состава».

${ }^{31}$ Цит. по: А. et В. с. Comité International Olympique, Fédération Internationale de Ski, Tribunal Arbitral du Sport, Arrêt du 27 mai 2003, p. 3.3.3.3. См.: http://www.tas-cas.org.

${ }^{32}$ Перевод осуществлен автром - Code of Sport-related Arbitration and Mediation Rules, Edition 2004. P. 148-157. 
2. Апелляционное арбитражное производство.

2.1. Арбитражная оговорка, включаемая в уставные документы федерации, ассоциации или другой спортивной организации:

«Любое решение, выносящееся... (включить название дисциплинарного суда или апелляционной инстанции федерации, ассоциации или спортивной организации, являющейся последней внутренней инстанцией), может быть передано для апелляционного обжалования исключительно в Спортивный Арбитражный Суд в Лозанне (Швейцария), который вынесет окончательное решение в споре в соответствии с Арбитражным Кодексом в области спорта. Срок внесения апелляции составляет 21 день со времени получения решения, являющегося предметом обжалования».

2.2. Согласие атлета на арбитражную оговорку.

Важно, чтобы атлеты явно выразили свое согласие в письменной форме с этим уставным положением. Они могут сделать это либо с помощью общего письменного заявления, применимого ко всем будущим спорам с федерацией, ассоциацией или спортивной организацией (как в нижеследующем пункте 1), либо с помощью письменной декларации, ограниченной конкретным спортивным мероприятием (образец в нижеследуюшем пункте 2).

a) Декларация общего типа.

«Я, нижеподписавшийся(аяся)... согласен(сна) с уставными документами (название федерации), в частности, с положением, предусматривающим исключительную компетенцию Спортивного Арбитражного Суда».

b) Декларация, ограниченная одним мероприятием.

«В рамках моего участия... (название мероприятия) я, нижеподписавшийся(аяся)..., согласен(сна) с тем, что любое решение, вынесенное последней внутренней инстанцией в связи с этим мероприятием, может стать предметом апелляционного оспаривания в Спортивном Арбитражном Суде в Лозанне (Швейцария) в соответствии с Арбитражным Кодексом в области спорта. Я согласен с полномочиями САС, исключая любые обращения в суды общей юрисдикции».

Внимание: Действительность оговорки, исключающей обращение в суды общей юрисдикщии, признается не во всех системах права. Федерациям и организаторам мероприятий рекомендуется проверить действительность данной оговорки в своей национальной системе права. 
3. Посредническое производство.

3.1. Рекомендуемая оговорка, включаемая в контракт.

«Любой спор, разногласие или требование, возникающие из настоящего контракта или любого последующего изменения настоящего контракта, или относящиеся к нему, и имеющие непосредственную, но не исключительную связь с его появлением, действительностью, неизбежными последствиями, интерпретацией, нарушением или прекрашением, как и любые внеконтрактные требования, будут переданы на посредническое урегулирование в соответствии с Регламентом посредничества САС. Языком посреднического производства будет...».

3.2. Дополнительное положение на случай недостижения разрешения спора.

«Если в течение 90 дней, которые следуют за внесением заявления, производство не привело к урегулированию спора или если до истечения указанного срока та или иная сторона отказывается от участия или от продолжения в участии в посредничестве, спор будет, по внесению арбитражного искового заявления одной из сторон, передан на рассмотрение арбитража САС для окончательного решения в соответствии с Арбитражным Кодексом в области спорта. Когда обстоятельства этого требуют, посредник, по собственной инициативе или по просьбе одной из сторон, может ходатайствовать перед Президентом САС о продлении срока». 